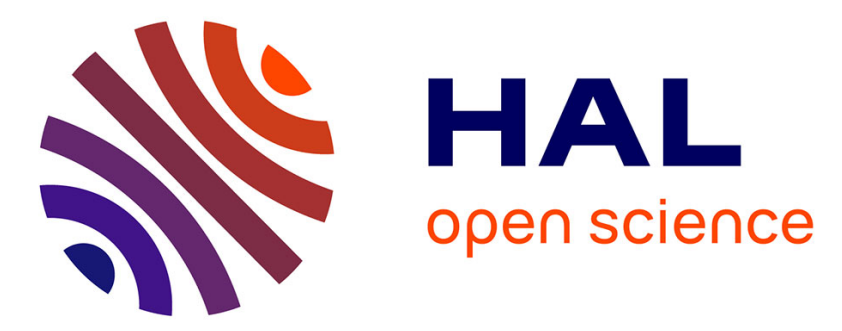

\title{
Activation of persulfate by irradiated laterite for removal of fluoroquinolones in multi-component systems
}

M. Kamagaté, A. Amin Assadi, T. Kone, L. Coulibaly, K. Hanna

\section{To cite this version:}

M. Kamagaté, A. Amin Assadi, T. Kone, L. Coulibaly, K. Hanna. Activation of persulfate by irradiated laterite for removal of fluoroquinolones in multi-component systems. Journal of Hazardous Materials, 2018, 346, pp.159-166. 10.1016/j.jhazmat.2017.12.011 . hal-01695559

HAL Id: hal-01695559

https://hal-univ-rennes1.archives-ouvertes.fr/hal-01695559

Submitted on 12 Mar 2018

HAL is a multi-disciplinary open access archive for the deposit and dissemination of scientific research documents, whether they are published or not. The documents may come from teaching and research institutions in France or abroad, or from public or private research centers.
L'archive ouverte pluridisciplinaire HAL, est destinée au dépôt et à la diffusion de documents scientifiques de niveau recherche, publiés ou non, émanant des établissements d'enseignement et de recherche français ou étrangers, des laboratoires publics ou privés. 


\section{Activation of persulfate by irradiated laterite for removal of fluoroquinolones in multi-component systems}

Mahamadou Kamagate ${ }^{12}$, Aymen Amin Assadi ${ }^{1}$, Tiangoua Kone ${ }^{2}$, Lacina Coulibaly ${ }^{2}$, Khalil Hanna*1

${ }^{1}$ Ecole Nationale Supérieure de Chimie de Rennes, UMR CNRS 6226, 11 Allée de Beaulieu,

$$
\text { F-35708 Rennes Cedex 7, France }
$$

${ }^{2}$ Université Nangui Abrogoua, 02 BP 801 Abidjan 02, Côte d'Ivoire

*Corresponding author. Tel: +33(0)223238027, Fax: +33(0)223238120, E-mail:

khalil.hanna@ensc-rennes.fr

\section{Graphical Abstract}

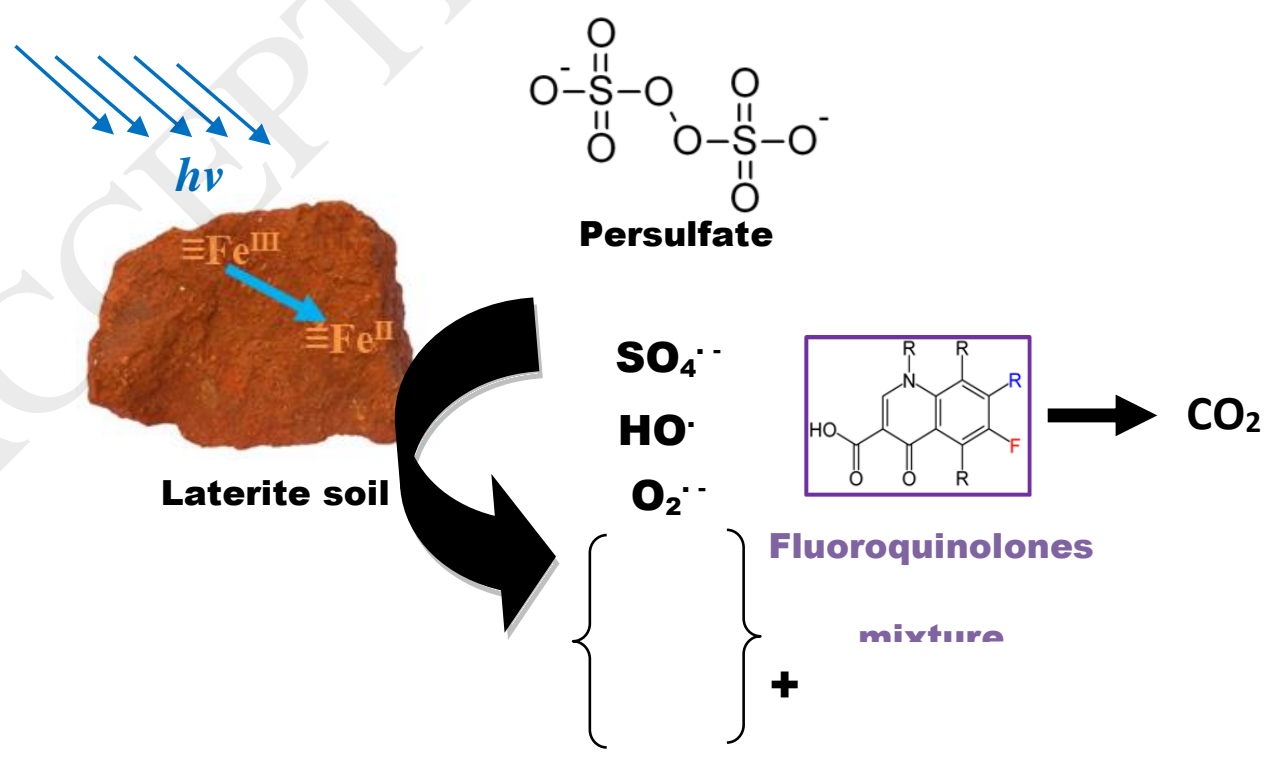




\title{
HIGHLIGHTS
}

- Laterite/PS/UVA is efficient to simultaneously remove three FQs

- Degradation rate constants can be ranked as follows: CIP > NOR > FLU.

- Degradation and mineralization extents decrease in binary/ternary systems.

- CIP oxidation in wastewater is less affected by FLU and NOR.

- An excellent catalytic stability of laterite in mixture systems.

\begin{abstract}
Although several emerging contaminants (e.g. fluoro(quinolones) (FQs)) have been simultaneously detected in environmental systems, there is very limited information on their elimination from contaminated waters in multi-component systems. In this study, removal of three FQs including flumequine (FLU), ciprofloxacin (CIP) and norfloxacin (NOR) were investigated in single and mixture systems, using natural laterite soil and persulfate (PS) under UVA irradiation. Both sorption and oxidation reactions contribute to the removal of FQs from aqueous phase, whereas quenching experiments showed that $\mathrm{SO}_{4}{ }^{-}$is mainly responsible for the FQs oxidation. The kinetic rate constants can be ranked as follows: CIP > NOR > FLU, regardless of whether the compound was alone or in mixture. The higher degradation rate constant of CIP relative to those of NOR and FLU could be explained by the high reactivity of $\mathrm{SO}_{4}{ }^{--}$radical with cyclopropane-ring containing compounds. Fall in oxidation performance was observed in synthetic wastewater, probably due to sulfate radical scavenging by wastewater components. However, degradation rate constants of CIP in wastewater remains unchanged in mixture systems as compared to single ones. This environmentally friendly remediation technology may appear as a promising way for the removal of fluoroquinolone antibiotics from multi-contaminated waters.
\end{abstract}

Keywords: fluoroquinolones; persulfate; laterite; oxidation, multi-components. 


\section{Introduction}

Because of increasing multiple contaminations in aquatic ecosystems worldwide, surface waters and groundwater often contain multiple contaminants including antibiotics (e.g. (fluoro)quinolones, sulfonamides and macrolides) [1, 2]. As a result of their releases from human and intensive farming activities, different compounds belonging to fluoroquinolones have been simultaneously detected in sediments and aquatic environments [3, 4]. Although affected environmental systems often contain contaminant mixtures, elimination mechanisms and competition effects in multi-component systems have been scarcely investigated. Indeed, most of previous works have mainly focused on removal processes in mono-component systems, and few works have been dedicated to develop cost-effective methods for the elimination of environmental contaminant mixtures $[5,6]$.

Activated persulfate oxidation processes (PS-AOPs) have received a growing attention to treat a wide range of contaminants in water $[7,8]$. In these processes, persulfate anion $\left(\mathrm{S}_{2} \mathrm{O}_{8}{ }^{2-}\right)$ is usually activated by thermal [9], alkaline [10], UVC [11] or transition metal [12-14] to form sulfate radical $\left(\mathrm{SO}_{4}{ }^{\bullet-}\right)$, which has high oxidation-reduction potential $\left(\mathrm{SO}_{4}{ }^{\circ} / \mathrm{SO}_{4}{ }^{2-}, E^{o}=2.6-3.2\right.$ $\mathrm{V}$ vs NHE). One of the most common activators of persulfate (PS) includes Fe under different forms, e.g. dissolved, colloidal or supported $[13,15]$.

To overcome the drawbacks of homogeneous reaction, heterogeneous activation using $\mathrm{Fe}$ solids may offer several advantages such as recovery/re-use of catalyst, no sludge formation, applicability for a wide range of $\mathrm{pH}$, etc. $[14,15]$. Different heterogeneous iron-containing catalysts have been used in oxidation processes, including synthetic and natural iron-bearing solids [11-16].

Laterite is an abundant porous and coarse soil, which has diverse minerals in oxide forms, and can be found in several parts of earth including Africa [16, 17]. Although some studies were 
dedicated to the use of laterite in Fenton reactions [16-19], much remains to be learned on the sorption/oxidation activity of this mineral and its catalytic stability.

In this present work, the ability of laterite to activate PS under UVA irradiation and then effectively remove mixture of emerging contaminants from water was assessed. Here, flumequine (FLU), norfloxacin (NOR) and ciprofloxacin (CIP), emerging contaminants belonging to fluoro(quinolone) (FQs) group, were used as target contaminants, which co-exist and persist in aquatic systems [20]. It was reported that these FQs concentrations ranged from $3 \mathrm{ng} \mathrm{L} \mathrm{L}^{-1}$ to $240 \mu \mathrm{g} \mathrm{L}^{-1}$ in hospital wastewaters and from $0.5 \mathrm{ng} \mathrm{L}^{-1}$ to $6.5 \mathrm{mg} \mathrm{L}^{-1}$ in the fresh surface water, which depend on location and sampling time [2]. Higher concentrations of FQs were also detected in the wastewater of drug producers ranging from $6 \mathrm{ng} \mathrm{L}^{-1}$ to $31 \mathrm{mg} \mathrm{L}^{-1}$ [21]. Removal of FQs from contaminated waters using PS-based oxidation processes have been recently investigated [22-27]. However, the use of laterite as sorbent/catalyst in the removal of FQs has never been investigated to date. Furthermore, most UV sources applied in PS activation studies are in the UVC range $\left(\lambda_{\mathrm{ex}} \sim 254 \mathrm{~nm}\right)[7,8,11]$, while UVA has recently received great attention [11, 22].

First, the influence of laterite loading and PS concentration on the removal efficiency rate was investigated. The effect of water matrices was then evaluated by performing oxidation tests in synthetic wastewaters (SWW). Competition effects were also investigated by determining kinetic rate constants and degradation percentages in single, binary and ternary systems. Finally, quenching experiments were conducted to identify the main reactive species in PS/UVA/laterite system. Moreover, catalytic stability of laterite was assessed by conducting sequential oxidation cycles in PS/UVA/Laterite system. The use of iron-containing soil may offer a cost-effective alternative for large-scale applications of water treatment, particularly in the developing countries. 


\section{Experimental}

\subsection{Materials}

Flumequine (FLU, 99\% purity), norfloxacin (NOR, 98\% purity) and ciprofloxacin (CIP, 98\% purity) were purchased from Sigma-Aldrich (St. Louis, USA). Potassium persulfate (PS) $\left(\mathrm{K}_{2} \mathrm{~S}_{2} \mathrm{O}_{8},>99,5 \%\right.$ purity), 1,10-phenanthroline (> 99\% purity), sodium acetate ( $>99 \%$ purity), and ferrous ammonium sulfate hexahydrate $\left(\left(\mathrm{NH}_{4}\right)_{2} \mathrm{Fe}\left(\mathrm{SO}_{4}\right)_{2} \cdot 6 \mathrm{H}_{2} \mathrm{O}\right)$ were obtained from Sigma-Aldrich. Hydrochloric acid ( $\mathrm{HCl}, 37 \%$ v/v), Sodium hydroxide (NaOH, $98 \%$ purity), Isopropanol (Isopr, $\mathrm{C}_{3} \mathrm{H}_{8} \mathrm{O}$ ), Tert-butanol (Tert-b, $\mathrm{C}_{4} \mathrm{H}_{10} \mathrm{O}$ ) and 1,4-Benzoquinone (BQ, $\mathrm{C}_{6} \mathrm{H}_{4} \mathrm{O}_{2}$ ) were also provided from Sigma-Aldrich. Solutions were prepared with high-purity water obtained from a Millipore Milli-Q system.

Laterite soil was collected from Ivory Coast, West Africa. The sample was grinded and passed through $250 \mu \mathrm{m}$ sieve, and then characterized by X-ray powder diffraction (D8 Bruker diffractometer). X-ray powder diffraction data revealed the presence of quartz, goethite, hematite, kaolinite and gibbsite (Fig. S1). However, the most abundant phases in our sample are quartz, goethite and hematite, which is in agreement with a previous work [17]. Consistently, the TEM-EDX indicated a composition of Fe, $\mathrm{Al}$ and $\mathrm{O}$ (i.e. under oxide forms), together with two major elements $\mathrm{Ca}$ and $\mathrm{Mg}$ (Fig. S1). More details are given in the supplementary material. To determine the metal contents in laterite, elements were analyzed using an inductively coupled plasma atomic emission spectrometer (ICP-AES, Jobin-Yvon JY 70 Type HORIBA) after acid digestion of the sample (Table S1). According to elemental composition analysis, the most abundant elements excluding Si are: Fe $\left(151 \mathrm{~g} \mathrm{~kg}^{-1}\right), \mathrm{Mn}(184$ $\left.\mathrm{mg} \mathrm{kg}{ }^{-1}\right), \mathrm{Cr}\left(170 \mathrm{mg} \mathrm{kg}^{-1}\right)$ and $\mathrm{Al}\left(83 \mathrm{mg} \mathrm{kg}^{-1}\right)$.

Potentiometric titrations of the laterite were conducted in thermostated double walled pyrex cell at $293 \mathrm{~K}$ in $0.001,0.01$ and $0.1 \mathrm{M} \mathrm{NaCl}$ solutions. The $\mathrm{pH}$ value of the suspensions was 
adjusted with titrant solutions $(\mathrm{HCl}$ or $\mathrm{NaOH})$. The Point Zero Charge (PZC) of laterite soil lied at $6.5 \pm 0.3$ (Fig. S2).

Based on the $\mathrm{N}_{2}$ adsorption/desorption isotherms (Fig. S2), the surface adsorption properties such as B.E.T. specific surface area, micro pore volume and total pore volume were determined as $23 \mathrm{~m}^{2} \mathrm{~g}^{-1}, 0.06 \mathrm{~m}^{3} \mathrm{~g}^{-1}$ and $0.07 \mathrm{~m}^{3} \mathrm{~g}^{-1}$, respectively.

\subsection{Photoreactor and Photodegradation experiments}

All experiments were performed in a $500 \mathrm{~mL}$ capacity batch photoreactor (made of borosilicate glass) at room temperature. The reactor was designed in a column shaped in 34 $\mathrm{cm}$ high and $3.8 \mathrm{~cm}$ diameter. This setup has an enclosed chamber comprising a reactor; an UVA lamp $24 \mathrm{~W}$ (Philips PL-L) placed in the center of the glass cell emitting in a wavelength region $320-400 \mathrm{~nm}$ with emission peak centered at $\lambda \max =360 \mathrm{~nm}$, yielding a irradiation intensity of $16 \mathrm{~mW} . \mathrm{cm}^{-2}$ as detected with a UVA Radiometer (VLX-3W equipped with a sensor CX 365, ALYS Technologies, Switzerland). The solution with catalyst was continuously stirred with a magnetic bar at $180 \mathrm{rpm}$. The $\mathrm{pH}$ and temperature of suspension were checked along the experiments.

Two different experiments were carried out beforehand at room temperature. In a first experiment, FQ solution and laterite were stirred overnight in the dark to reach the adsorption equilibrium without UVA irradiation and PS. In the second test, FQ solution, PS, and laterite were mixed simultaneously under UVA irradiation.

Photodegradation experiments were carried out for FLU, NOR and CIP in single, binary and ternary systems. Water samples were spiked with each molecule separately (single-component experiments at $77 \mu \mathrm{M}$ ), or with mixture of two or three molecules in equimolar concentrations (mixture experiments). 
Aqueous concentrations of FLU, CIP and NOR were determined using a high performance liquid chromatography (Waters 600 Controller) equipped with a reversed-phase C18 column (250 $\mathrm{mm} \times 4.6 \mathrm{~mm}$ i.d.,5 $\mu \mathrm{m}$ ) and UV detector (Waters 2489). The detector was set to 246, 275, $277 \mathrm{~nm}$ for FLU, CIP and NOR, respectively. The mobile phase was a mixture of acetonitrile/water (30/70 v/v) contained $0.1 \%$ formic acid. The flow rate was set at $1 \mathrm{~mL} \mathrm{~min}{ }^{-1}$ in isocratic mode. Under these conditions, the retention times of FLU, NOR and CIP were 6.5, 8 and 5 min, respectively. Total Organic Carbon (TOC) was determined using a TOCmeter (Shimadzu TOC-VCSH). Total dissolved iron concentrations were measured by the 1,10-phenantrholine method at $510 \mathrm{~nm}$ [28]. The scavenging experiments were performed using $100 \mathrm{mM}$ of Isopr, Tert-b and BQ each, to determine the contributions of $\mathrm{SO}_{4}{ }^{-}, \cdot \mathrm{OH}$ and $\mathrm{HO}_{2} / \mathrm{O}_{2}{ }^{-}$in the degradation of NOR. The optimum concentration of scavengers (i.e. 100 $\mathrm{mM}$ ) was obtained, according to a preliminary study (Fig. S3). The possible release of trace elements such as $\mathrm{Cr}, \mathrm{Mn}, \mathrm{Cu}, \mathrm{Co}, \mathrm{Ni}$ and $\mathrm{Zn}$ from laterite surfaces was also checked by ICP/AES, which indicated that these elements were under quantification limits (i.e. $0.1 \mu \mathrm{g} \mathrm{\textrm {L } ^ { - }}$ ${ }^{1}$ ) under our experimental conditions. Residual PS concentration was monitored by a UV-vis spectrophotometer (Varian, 50 Probe) at $352 \mathrm{~nm}$ according to the modified method of Liang et al. [29]. All experimental runs were performed in triplicates within a temperature of $20 \pm$ $1{ }^{\circ} \mathrm{C}$. All results were expressed as a mean value of the 3 experiments.

\section{Results and discussion}

\subsection{Removal efficiencies of single components}

The kinetics of FLU, NOR and CIP removal using different oxidation processes in presence and absence of laterite are shown in Figure 1. First, the direct photolysis is less than $12 \%$. The observed degradation in PS/UVA may result from the photochemical activation of PS generating sulfate radicals (i.e. $\mathrm{S}_{2} \mathrm{O}_{8}{ }^{2-}+\mathrm{h} v \rightarrow 2 \mathrm{SO}_{4}{ }^{-}$), though PS activation is supposed to be 
low in UVA. Indeed, PS activation decreases as photolytic wavelength increases, as the extinction coefficients of UV photolytic persulfate activation at 248,308 , and $351 \mathrm{~nm}$ are $27.5,1.18$, and $0.25 \mathrm{~mol}^{-1} \mathrm{~cm}^{-1}[30]$.

The heterogeneous process (i.e. PS/UVA/laterite) showed the best removal performance, with $63 \%, 72 \%$ and $79 \%$ for respectively FLU, NOR and CIP, suggesting synergetic effect of laterite and UVA for PS activation. To account for the sorption on laterite, desorption tests (with addition $\mathrm{NaOH}$ to $\mathrm{pH} 11$ ) were carried out and total amounts of FLU, NOR and CIP in aqueous phase were plotted versus time (see Fig. 1). Indeed, the yields of degradation of FLU, NOR and CIP were 53\%, 63\% and $73 \%$ at $\mathrm{pH} 6.5 \pm 0.1$, respectively. The amounts of degraded compounds were found slightly lower than the removal amounts (as illustrated by $[\mathrm{FLU}]_{\text {tot }} v s[\mathrm{FLU}]_{\mathrm{aq}}$ in Fig. 1), whereas the adsorbed amounts of FLU, NOR and CIP lied at $10 \%, 9 \%$ and $6 \%$, respectively. An overnight pre-equilibration of compound with laterite suspension in the dark before oxidation did not significantly change the kinetic behavior (see e.g. Fig. S4 for FLU). TOC measurements confirmed the oxidative degradation in PS/UVA/laterite system, with $30 \%, 43 \%$ and $55 \%$ of mineralization achieved for FLU, NOR and CIP, respectively (Fig. S5a). The Fe leaching of laterite surfaces in PS/UVA/laterite

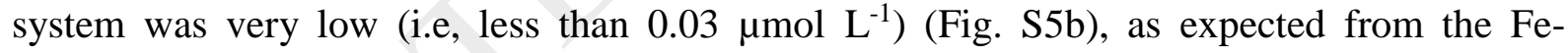
solubility equilibrium at $\mathrm{pH} 6.5 \pm 0.1$.

Therefore, the efficiency of laterite combined with UVA irradiation could be attributed to the higher production of reactive oxygen species (e.g. $\mathrm{SO}_{4}{ }^{-},{ }^{\circ} \mathrm{OH}$ and $\mathrm{HO}_{2}{ }^{\circ} / \mathrm{O}_{2}{ }^{\circ}$ ). These radicals could be directly generated from PS under the assistance of the redox cycle of $\equiv \mathrm{Fe}^{\mathrm{III}} / \equiv \mathrm{Fe}^{\mathrm{II}}$ on laterite surfaces promoted by UVA irradiation, as previously reported [31, 32]:

$\equiv \mathrm{Fe}^{\mathrm{III}} \mathrm{OH}^{2+}+h v \rightarrow \equiv \mathrm{Fe}^{\mathrm{II}}+\cdot{ }^{\circ} \mathrm{OH}$

Indeed, $\mathrm{Fe}(\mathrm{II})$ could be generated via photo-reduction of $\mathrm{Fe}(\mathrm{III})$-sites on laterite surfaces, which in turn reacts with PS to generate $\mathrm{SO}_{4}{ }^{--}$following: 
$\equiv \mathrm{Fe}^{\mathrm{II}}+\mathrm{S}_{2} \mathrm{O}_{8}{ }^{2-} \longrightarrow \equiv \mathrm{Fe}^{\mathrm{III}}+\mathrm{SO}_{4}{ }^{--}+\mathrm{SO}_{4}{ }^{2-} \quad k=2.7 \times 10^{1} \mathrm{M}^{-1} \mathrm{~s}^{-1} \quad[31,32]$

Then, ${ }^{\circ} \mathrm{OH}$ could be also generated through the reactions between the $\mathrm{SO}_{4}{ }^{\circ}$ and $\mathrm{H}_{2} \mathrm{O} / \mathrm{HO}^{-}$:

$\mathrm{SO}_{4}{ }^{--}+\mathrm{H}_{2} \mathrm{O} \longrightarrow \mathrm{SO}_{4}{ }^{2-}+{ }^{\circ} \mathrm{OH}+\mathrm{H}^{+} \quad k\left[\mathrm{H}_{2} \mathrm{O}\right]=1.3 \times 10^{3} \mathrm{~s}^{-1} \quad[33,34]$

$\mathrm{SO}_{4}{ }^{--}+\mathrm{OH}^{-} \longrightarrow \mathrm{SO}_{4}{ }^{2-}+{ }^{\circ} \mathrm{OH} \quad(\mathrm{pH}>8.5) \quad k=6.5 \pm 1 \times 10^{7} \mathrm{M}^{-1} \mathrm{~s}^{-1}$

Moreover, $\mathrm{SO}_{4}{ }^{-}$and ${ }^{\circ} \mathrm{OH}$ could be also formed through chain reactions dominated by the superoxide anion radical [36]:

$$
\begin{aligned}
& \equiv \mathrm{Fe}^{\mathrm{II}}+\mathrm{O}_{2} \longrightarrow \equiv \mathrm{Fe}^{\mathrm{III}}+\mathrm{O}_{2}^{--} \\
& \mathrm{S}_{2} \mathrm{O}_{8}{ }^{2-}+\mathrm{O}_{2}^{\cdot-} \longrightarrow \mathrm{SO}_{4}{ }^{--}+\mathrm{O}_{2}+\mathrm{SO}_{4}^{2-} \\
& 2 \mathrm{O}_{2}{ }^{--}+2 \mathrm{H}^{+} \longrightarrow \mathrm{H}_{2} \mathrm{O}_{2}+\mathrm{O}_{2} \\
& \equiv \mathrm{Fe}^{\mathrm{II}}+\mathrm{H}_{2} \mathrm{O}_{2} \longrightarrow \equiv \mathrm{Fe}^{\mathrm{III}}+{ }^{\cdot} \mathrm{OH}+\mathrm{OH}^{-}
\end{aligned}
$$

To get further insights into the reaction mechanism, quenching studies using scavengers were performed to identify the main radical species involved in PS/UVA/laterite system. First, isopropanol was supposed to quench efficiently both generated $\mathrm{SO}_{4}{ }^{-}$and ${ }^{\circ} \mathrm{OH}$ considering the second order rate constants of $k_{\text {Isopr, SO4 }}{ }^{--}=7.42 \times 10^{7} \mathrm{M}^{-1} \mathrm{~s}^{-1}$ and $k$ Isopr, $\cdot \mathrm{OH}=1.9 \times 10^{9} \mathrm{M}^{-1} \mathrm{~s}^{-1}$ (very high concentration of scavengers $(100 \mathrm{mM})$ were used according to preliminary optimization tests, Fig. S6), while Tert-b can be considered to be more selective toward ${ }^{\circ} \mathrm{OH}$ $\left(k_{\text {Tert-b }}, \cdot \mathrm{OH}=6.0 \times 10^{8} \mathrm{M}^{-1} \mathrm{~s}^{-1}\right)$ than $\mathrm{SO}_{4}{ }^{--}\left(k_{\text {Tert-b, }} \mathrm{SO}^{{ }^{-}}=8.31 \times 10^{5} \mathrm{M}^{-1} \mathrm{~s}^{-1}\right)$ [37, 38]. It is then possible to estimate the radical scavenging percentage by using the aqueous concentration of each chemical and the reactivity of radicals with NOR $\left(k\right.$ NOR, SO ${ }^{\cdot-}=10^{7}-10^{10} \mathrm{M}^{-1} \mathrm{~s}^{-1}[39]$ and $k_{\mathrm{NOR}}{ }^{\circ} \mathrm{OH}=1.0-6.2 \times 10^{9} \mathrm{M}^{-1} \mathrm{~s}^{-1}[40,41]$ ) (more detail is given in supplementary material). With $k$ NOR, $\mathrm{SO}^{-{ }^{-}}=10^{7} \mathrm{M}^{-1} \mathrm{~s}^{-1}$, more than $99 \%$ of $\mathrm{SO}_{4}{ }^{-}$would be quenched with Isopr or Tert$b$. With $k$ NOR, $\mathrm{SO}^{\cdot-}=10^{10} \mathrm{M}^{-1} \mathrm{~s}^{-1}$, about $91 \%$ and $10 \%$ of $\mathrm{SO}_{4}{ }^{--}$could be scavenged by Isopr and Tert-b, respectively (Fig.S6). It is worth noting that the bimolecular reaction rate 
constants with radicals were mostly determined at $\mathrm{pH}$ buffered to 7 ( $\mathrm{pKa}_{1}<\mathrm{pH}<\mathrm{pKa}$ ), where the zwitterionic form of NOR is the predominant species (See Fig. S7 for distribution of NOR species at various $\mathrm{pH}$ values). In the present work, the oxidation reactions were conducted at $\mathrm{pH} 6.5 \pm 0.1$ where both protonated and zwitterionic (or neutral) forms may co-exist.

In the presence of Isopr, about $14 \%$ of degradation of NOR was still observed, whereas $49 \%$ of NOR degradation was inhibited with respect to the degradation without scavengers. $14 \%$ of inhibition was observed using Tert-b, and there was still $49 \%$ of NOR degradation (Fig. 2a). We can suppose that the difference observed in NOR degradation (i.e. 35\%) when the scavengers were used separately should correspond to the contribution of $\mathrm{SO}_{4}{ }^{*-}$.

Addition of BQ to Isopr in PS/UVA/laterite system inhibited completely the degradation of NOR (difference between Isopr $+\mathrm{BQ}$ and Isopr $=4 \%)$. It is well known that $\mathrm{BQ}\left(k \mathrm{BQ}, \mathrm{HO}^{\circ} / \mathrm{O} 2^{\circ}\right.$ $\left.=9.6 \times 10^{8} \mathrm{M}^{-1} \mathrm{~s}^{-1}\right)$ is an electron acceptor able to interrupt dissolved oxygen accepting electrons, and so acts as a very effective trap to avoid the formation of radical couple (hydroperoxyle radical /superoxide radical anion, $\mathrm{HO}_{2}{ }^{\circ} / \mathrm{O}_{2}{ }^{-}$) $[11,42]$. It is then possible that $\mathrm{O}_{2}{ }^{-{ }^{-}}$can be formed in our experimental conditions $\left(\mathrm{pH}=6.5>\mathrm{pKa}\left(\mathrm{HO}_{2}{ }^{\circ} / \mathrm{O}_{2}{ }^{\circ}\right)\right.$, as shown in eq.5. Since $35 \%, 14 \%$ and $14 \%$ of degradation of NOR were due to $\mathrm{SO}_{4}{ }^{\circ-}$, ${ }^{\circ} \mathrm{OH}$ and $\mathrm{O}_{2}{ }^{\circ-}$, respectively, the relative contributions of $\mathrm{SO}_{4}{ }^{--},{ }^{\circ} \mathrm{OH}$ and $\mathrm{O}_{2}{ }^{--}$for NOR degradation $(63 \%)$ were estimated as $56 \%, 22 \%$ and $22 \%$, respectively (Fig. 2b).

\subsection{Effects of PS concentration and laterite loading}

Removal kinetics of FLU and NOR were determined for a range of PS concentration (0.4 - 2 $\mathrm{mM})$ and laterite loading $\left(0.5-4 \mathrm{~g} \mathrm{~L}^{-1}\right)$ at $\mathrm{pH} 6.5 \pm 0.1$. Assuming that FLU or NOR was mainly degraded by sulfate radical species, the degradation kinetic can be described as a second-order reaction: 


$$
\frac{d[F L U]}{d t}=-k[F L U]\left[S O_{4}^{--}\right]
$$

where $\left[\mathrm{SO}_{4}{ }^{-}\right]$is steady-state concentration of sulfate radical, [FLU] is concentration of FLU in water, $k$ is the second-order rate constant, and $t$ is the reaction time. By assuming that $\mathrm{SO}_{4}{ }^{-}$ instantaneous concentration is constant, the kinetics of FLU degradation in water can be described according to the pseudo-first-order equation as given below:

$$
[F L U]_{t}=[F L U]_{0} \exp \left(-k_{a p p} t\right)
$$

where $k_{a p p}$ is the pseudo-first-order apparent rate constant $\left(\min ^{-1}\right) . k_{a p p}\left(\min ^{-1}\right)$ obtained by linear regression of $\ln \left([\mathrm{FLU}]_{\mathrm{t}} /[\mathrm{FLU}]_{\mathrm{o}}\right)$ versus time $t$, was plotted versus PS concentration or laterite loading (Fig. 3).

Firstly, kinetic rate constant increased with increasing amount of PS from 0.4 to $0.7 \mathrm{mM}$, reached an optimum value and then decreased at higher PS concentrations (Fig.3a), probably due to the scavenging effect of $\mathrm{SO}_{4}{ }^{-}$- radical by PS and/or recombination of radicals [43] as following:

$$
\begin{array}{ll}
\mathrm{SO}_{4}{ }^{--}+\mathrm{S}_{2} \mathrm{O}_{8}{ }^{2-} \longrightarrow \mathrm{SO}_{4}{ }^{2-}+\mathrm{S}_{2} \mathrm{O}_{8}{ }^{--} & k=6.62 \times 10^{5} \mathrm{M}^{-1} \mathrm{~s}^{-1} \\
\mathrm{SO}_{4}{ }^{-}+\mathrm{SO}_{4}{ }^{-} \longrightarrow \mathrm{S}_{2} \mathrm{O}_{8}{ }^{2-} & k=8.1 \times 10^{8} \mathrm{M}^{-1} \mathrm{~s}^{-1}
\end{array}
$$

Total consumption of PS was achieved for all PS concentrations, except for the highest concentration (i.e. $2 \mathrm{mM}$ ). For the latter, about $50 \%$ of initial PS concentration was detected at the end of reaction time (See Fig. S8). Here, we note that the optimal PS concentration for the degradation rate of FLU and NOR is around $0.7 \mathrm{mM}$, where PS has been totally disappeared after 500 min of reaction time. At this concentration of PS, the degradation rate constant of NOR $\left(2.2 \times 10^{-3} \mathrm{~min}^{-1}\right)$ is slightly higher than that for FLU $\left(1.8 \times 10^{-3} \mathrm{~min}^{-1}\right)$ (Fig. 3a). Likewise, kinetic rate constants first increased with laterite loading and then decreased (Fig. 3b). When the laterite concentration varied from 0 to $1 \mathrm{~g} \mathrm{~L}^{-1}$, the first-order rate constants for 
the removal efficiency increased from $7.10^{-4}$ to $1.8 .10^{-3} \mathrm{~min}^{-1}$ for FLU and $6.10^{-4}$ to $2.2 .10^{-3}$ $\min ^{-1}$ for NOR. The fall observed at higher laterite loadings can be explained by screening effects occurring at high solid loading in aqueous suspension and/or scavenging effects of involved radicals by laterite $[16,44]$. For instance, excessive $\mathrm{Fe}$-sites can act as $\mathrm{SO}_{4}{ }^{\bullet}$-radical scavenger as follows [45]:

$\mathrm{SO}_{4}{ }^{-}+\equiv \mathrm{Fe}^{\mathrm{II}} \longrightarrow \mathrm{SO}_{4}{ }^{2-}+\equiv \mathrm{Fe}^{\mathrm{III}} \quad k=3 \times 10^{8} \mathrm{M}^{-1} \mathrm{~s}^{-1}$

As shown in Fig.3b, the optimal laterite loading is around $1 \mathrm{~g} \mathrm{~L}^{-1}$, regardless of the target compound.

\subsection{Degradation of fluoroquinolones (FQs) in mixture systems}

In order to evaluate the effectiveness of PS/UVA/laterite system for removal of FQs in multicomponent systems, pseudo-first-order apparent rate constants were determined for FLU, NOR and CIP in single, binary and ternary systems using the optimum conditions $(0.7 \mathrm{mM}$ of PS and $1 \mathrm{~g} \mathrm{~L}^{-1}$ of laterite) (Fig.4).

The kinetic rate constants can be ranked as follows: CIP > NOR > FLU, regardless of the investigated system (single, binary or ternary). While both $\mathrm{SO}_{4}{ }^{-}$and ${ }^{\circ} \mathrm{OH}$ can be produced simultaneously in such process, $\mathrm{SO}_{4}{ }^{-}$preferenially reacts with target compounds via electron transfer mechanism and ${ }^{\circ} \mathrm{OH}$ through hydrogen abstraction or addition reactions [36]. The higher degradation rate constant of CIP relative to those of NOR and FLU could be explained by the high reactivity of $\mathrm{SO}_{4}{ }^{--}$radical with the cyclopropane ring of CIP [23]. Indeed, Jiang et al. [23] have compared the different transformation pathways and oxidation byproducts of CIP and enrofloxacin (ENR), two compounds containing cyclopropane ring, with those of norfloxacin and ofloxacin (cyclopropane ring free). First, the most important degradation pathway is initiated by piperazine ring cleavage followed by stepwise oxidation caused by $\mathrm{SO}_{4}{ }^{-}$attack. Indeed, $\mathrm{SO}_{4}{ }^{--}$radical preferentially reacts as an electron acceptor with the $\mathrm{N}$ 
atoms on the piperazine ring containing lone pair electrons [46]. This concerns CIP and NOR, but not FLU that lacks the characteristic piperazine ring. Second, an additional degradation pathway can be initiated by the cleavage of the cyclopropane moiety (e.g. in case of CIP) via loss of one $\mathrm{CH}_{2}$ unit [23] or two $\mathrm{CH}_{2}$ units [24]. Consistently, Sturini et al. [47] reported that degradation rates of three compounds containing cyclopropane ring (i.e., CIP, ENR and danofloxacin) were greater than those without cyclopropane ring (i.e., levofloxacin, marbofloxacin and moxifloxacin).

In binary systems, the kinetic rate constants of CIP decreased from $17.10^{-3} \mathrm{~min}^{-1}$ to $12.10^{-3}$ $\mathrm{min}^{-1}$ in CIP/FLU mixture and to $10.10^{-3} \mathrm{~min}^{-1}$ in CIP/NOR mixture. Similar conclusion can be drawn for the two other compounds, i.e. the kinetic rate constants decreased in binary as compared to single systems (Fig. 4a). In the ternary mixture (CIP/NOR/FLU), the kinetic rate constants of CIP, NOR and FLU fall down to $9.9 .10^{-3} \mathrm{~min}^{-1}, 4.4 .10^{-3} \mathrm{~min}^{-1}$ and $3.1 .10^{-3} \mathrm{~min}^{-1}$, respectively (Fig. 4a). Consistently, the degradation percentages decreased in mixture systems, as compared to those of single compounds (Fig. 4b).

\subsection{Effect of water matrices}

To assess the ability of PS/UVA/laterite system to remove FQs under environmentally relevant conditions, pseudo-first-order apparent rate constants were determined for FLU, NOR and CIP in single, binary and ternary systems as previously explained, but in synthetic wastewaters (SWW). Synthetic wastewater (SWW) were prepared by adding $400 \mathrm{mg} \mathrm{L}^{-1}$ of $\mathrm{NaCl}, 50 \mathrm{mg} \mathrm{L}^{-1}$ of citric acid, $30 \mathrm{mg} \mathrm{L}^{-1}$ of ascorbic acid, $100 \mathrm{mg} \mathrm{L}^{-1}$ of saccharose and 230 $\mathrm{mg} \mathrm{L}^{-1} \mathrm{Na}_{2} \mathrm{HPO}_{4}$ to tap water (conductivity $457 \mu \mathrm{S} \mathrm{cm}^{-1}, \mathrm{Cl}^{-} 0.15 \mathrm{mg} \mathrm{L}^{-1}, \mathrm{SO}_{4}^{2-} 7.31 \mathrm{mg} \mathrm{L}^{-1}$, $\mathrm{NO}_{3}{ }^{-} 34.7 \mathrm{mg} \mathrm{L}^{-1}$, DOC $0.254 \mathrm{mg} \mathrm{L}^{-1}$ ) and adjusting $\mathrm{pH}$ to $7.25 \pm 0.1$. This composition resembles that of pharmaceutical industry wastewater [48]. 
As previously observed in pure water, degradation rate constants as well as degradation percentages decreased in binary or ternary systems with respect to those observed for individual compounds (Fig. 5). However, strong inhibition of CIP degradation was observed in SWW, as compared to those measured in pure water regardless of the investigated system (single or mixture). Indeed, 4-fold decrease in degradation rate constant (from $17.10^{-3} \mathrm{~min}^{-1}$ to 4.1.10-3 $\mathrm{min}^{-1}$ ) was observed for CIP, while less than 2-fold decrease was observed for NOR or FLU (Figs. 4a and 5a). This may result from the higher reactivity of CIP with sulfate radicals, which make it more subject for scavenging effects than NOR or FLU. In fact, SWW components may compete with target compounds for reaction with radical species and particularly sulfate radical. For instance, chloride ion $\left(400 \mathrm{mg} \mathrm{L}^{-1}\right)$ participates to the quenching of $\mathrm{SO}_{4}{ }^{\bullet-}\left(k_{\mathrm{SO}_{4}^{--}, \mathrm{Cl}^{-}}=2.0 \times 10^{8} \mathrm{M}^{-1} \mathrm{~s}^{-1}\right.$ [24] $)$ to generate $\mathrm{Cl}^{\bullet}$ which rapidly combines with another chloride ion in water forming dichloride radical anion $\left(\mathrm{Cl}_{2}{ }^{\bullet-}\right) k_{\mathrm{Cl}}{ }^{,} \mathrm{Cl}^{-}=0.8-2.1 \times$ $10^{10} \mathrm{M}^{-1} \mathrm{~s}^{-1}$ [46]. Other SWW components, such as phosphates, saccharose or citrate could also actively contribute to sulfate radical scavenging. It is worth noting that, unlike NOR or FLU, no significant decrease in kinetic rate constants or degradation percentages was observed for CIP in mixture systems as compared to single ones (Fig. 5). In conclusion, these results show that CIP oxidation was more affected by SWW components than by the presence of co-occurring FQs (i.e. FLU and NOR).

\subsection{Reusability of laterite}

The reusability of laterite has been evaluated over three successive oxidation cycles, with the above-mentioned optimum conditions, at $\mathrm{pH} 6.5 \pm 0.1$ and in the ternary system (Fig. 6). At the end of the oxidation process, the solid was easily removed from the reactor, washed with ultra-pure, and dried at $50^{\circ} \mathrm{C}$ overnight, and then used for next experiment. Thus, the degradation efficiencies using the recovered solid of FLU, NOR and CIP, remained stable 
during the three oxidation cycles with $52 \pm 3 \%, 64 \pm 3 \%$, and $73 \pm 3 \%$ respectively. Mineralization extent remained also unchanged, with $32 \pm 4 \%, 44 \pm 4 \%$ and $55 \pm 4 \%$ for FLU, NOR, and CIP respectively. Therefore, the good stability of the catalytic activity of laterite could be attributed to the very low iron leaching during oxidation cycles and to the structural stability of the solid. The latter was checked by recording XRD diffractogram at the end of oxidation reaction, which exhibits no change with that obtained before reaction (Fig.S1).

\section{Conclusion}

This paper demonstrated that laterite soil under UVA irradiation can activate PS to mainly generate $\mathrm{SO}_{4}{ }^{--}$and effectively remove FQs such as FLU, NOR and CIP. Quenching experiments showed implications of $\mathrm{SO}_{4}{ }^{-},{ }^{\circ} \mathrm{OH}$ and couple $\mathrm{HO}_{2}{ }^{\circ} \mathrm{O}_{2}{ }^{--}$in the degradation of FQs, but $\mathrm{SO}_{4}{ }^{--}$was the most involved radical in FQs degradation. The kinetic rate constants can be ranked as follows: CIP > NOR > FLU, regardless of the investigated system (single, binary or ternary). The higher degradation rate constant of CIP relative to those of NOR and FLU could be explained by the high reactivity of $\mathrm{SO}_{4}{ }^{--}$radical with cyclopropane ring. In pure water, kinetic rate constants were found lower in binary/ternary systems with respect to those of individual compounds. Unlike FLU and NOR, strong inhibition of CIP degradation was observed in wastewater, probably due to sulfate radical scavenging. However, no significant decrease in kinetic rate constants was observed for CIP in mixture systems as compared to single ones. Collectively, these results showed that CIP oxidation was less impacted by the presence of FLU and NOR, particularly in wastewater. The laterite can be re-used for several oxidation cycles without structural changes or deactivation of surface sites, but water washing and drying processes were applied before re-use in a new oxidation cycle. This new PS- 
activation process may promote the development of a cost-effective technology of water remediation, for the removal of emerging compounds in multi-contaminated systems.

\section{Acknowledgements}

This work was supported by a bilateral governmental program (Contract C2D) and Campus

France. We gratefully acknowledge Dr. M. Pasturel (Rennes University) for XRD analysis and Dr. S. Rtimi (EPFL, Lausanne) for TEM analysis.

\section{Supplementary data}

Supplementary data associated with this article can be found, in the online version. 


\section{References}

[1] D. W. Kolpin, E. T. Furlong, M. T. Meyer, E. M. Thurman, S. D. Zaugg, L. B. Barber, H. T. Buxton, Pharmaceuticals, hormones, and other organic wastewater contaminants in US streams, 1999-2000: A national reconnaissance, Environ. Sci. Technol. 36 (6) (2002) 12021211.

[2] X. Van Doorslaer, J. Dewulf, H. Van Langenhove, K. Demeestere, Fluoroquinolone antibiotics: An emerging class of environmental micropollutants, Sci. Total Environ. 500-501 (2014) 250-269

[3] D. Fatta-Kassinos, S. Meric, A. Nikolaou, A. Pharmaceutical, residues in environmental waters and wastewater: Current state of knowledge and future research, Anal. Bioanal. Chem. 399 (1) (2011) 251-275.

[4] M. D. Hernando, M. Mezcua, A. R. Fernández-Alba, D. Barceló, Environmental risk assessment of pharmaceutical residues in wastewater effluents, surface waters and sediments. Talanta 69 (2) (2006) 334-342.

[5] S. S. Suthersan, J. Horst, M. Schnobrich, N. Welty, J. McDonough. Remediation Engineering: Design Concepts, Second Edition, 2016 CRC Press.

[6] R. R. Krishna, Special Issue on Contaminant Mixtures: Fate, Transport, and Remediation. Journal of Hazardous, Toxic, and Radioactive Waste 15 (3) (2011).

[7] P. Devi, U. Das, A. K. Dalai, In-situ chemical oxidation: principle and applications of peroxide and persulfate treatments in wastewater systems, Sci. Total Environ. 571(2016) 643657.

[8] A. Tsitonaki, B. Petri, M. Crimi, H. Mosbæk, R. L. Siegrist, P. L. Bjerg, In situ chemical oxidation of contaminated soil and groundwater using persulfate: a Review, Crit. Rev. Environ. Sci. Technol. 40 (1) (2010) 55-91.

[9] H. Guo, N. Gao, Y. Yang, Y. Zhang, Kinetics and transformation pathways on oxidation of fluoroquinolones with thermally activated persulfate, Chem. Eng. J. 292 (2016) 82-91.

[10] G. Fang, J. Gao, D. D. Dionysiou, C. Liu, D. Zhou, Activation of Persulfate by Quinones: Free Radical Reactions and Implication for the Degradation of PCBs, Environ. Sci. Technol. 47 (2013) 4605-4611.

[11] J. M. Monteagudo, A. Durán, I. S. Martin, A. Carnicer, Roles of different intermediate active species in the mineralization reactions of phenolic pollutants under a UV-A/C photoFenton process, Appl. Catal. B Environ.106 (2011) 242-249.

[12] Q. Yang, H. Choi, D. D. Dionysiou, Nanocrystalline cobalt oxide immobilized on titanium dioxide nanoparticles for the heterogeneous activation of peroxymonosulfate, Appl. Catal. B Environ. 74 (2007) 170-178.

[13] Y. Lei, C.-S. Chen, Y.-J. Tu, Y.-H. Huang, H. Zhang, Heterogeneous degradation of organic pollutants by persulfate activated by $\mathrm{CuO}-\mathrm{Fe}_{3} \mathrm{O}_{4}$ : mechanism, stability, and effects of pH and bicarbonate ions, Environ. Sci. Technol. 49 (2015) 6838-6845. 
[14] Y. Wu, R. Prulho, M. Brigante, W. Dong, K. Hanna, G. Mailhot, Activation of persulfate by Fe (III) species: Implications for 4-tert-butylphenol degradation, J. Hazard. Mater. 322 (2017) 380-386.

[15] P. Avetta, A. Pensato, M. Minella, M. Malandrino, V. Maurino, C. Minero, K. Hanna, D. Vione, Activation of Persulfate by Irradiated Magnetite: Implications for the Degradation of Phenol under Heterogeneous Photo-Fenton-Like Conditions, Environ. Sci. Technol. 49 (2015) 1043-1050.

[16] A. Khataee, F. Salahpour, M. Fathinia, B. Seyyedi, B. Vahid, Iron rich laterite soil with mesoporous structure for heterogeneous Fenton-like degradation of an azo dye under visible light, J. Ind. Eng. Chem. 26 (2015) 129-135.

[17] L. S. Coulibaly, S. K. Akpo, J. Yvon, L. Coulibaly, Fourier transform infra-red (FTIR) spectroscopy investigation, dose effect, kinetics and adsorption capacity of phosphate from aqueous solution onto laterite and sandstone, J. Environ. Manag. 183 (2016) 1032-1040.

[18] B. Manu, S. Mahamood, Degradation of Paracetamol in Aqueous Solution by Fenton Oxidation and Photo-Fenton Oxidation Processes Using Iron from Laterite Soil as Catalyst, Int. J. Earth sci. Eng. 4 (6) (2011) 1103 - 1110.

[19] A. R. Khataee, S. G. Pakdehi, Removal of sodium azide from aqueous solution by Fenton-like process using natural laterite as a heterogeneous catalyst: Kinetic modeling based on nonlinear regression analysis, J. Taiwan Inst. Chem. E. 45 (2014) 2664-2672.

[20] R.Gothwal, T. Shashidhar, Antibiotic Pollution in the Environment: A Review, CLEANSoil, Air, Water. 43 (4) (2015) 479-489.

[21] W. J. Sim, J. W. Lee, E. S. Lee, S. K. Shin, S. R. Hwang, J. E. Oh, Occurrence and distribution of pharmaceuticals in wastewater from households, livestock farms, hospitals and pharmaceutical manufactures, Chemosphere 82 (2011) 179-186.

[22] C. A. L. Graça, A. Correia de Velosa, A. C. S. C. Teixeira, Amicarbazone degradation by UVA-activated persulfate in the presence of hydrogen peroxide or $\mathrm{Fe}^{2+}$, Catal. Today, 280 (2017) 80-85.

[23] C. Jiang, Y. Ji, Y. Shi, J. Chen, T. Cai, Sulfate radical-based oxidation of fluoroquinolone antibiotics: Kinetics, mechanisms and effects of natural water matrices, Water Res. 106 (2016) 507-517.

[24] H. Guo, T. ke, N. Gao, Y. Liu, X. Cheng, Enhanced degradation of aqueous norfloxacin and enrofloxacin by UV-activated persulfate: Kinetic, pathways and deactivation, Chem. Eng. J. 316 (2017) 471-480.

[25] I. Epold, M. Trapido, N. Dulova, Degradation of levofloxacin in aqueous solutions by Fenton, ferrous ion-activated persulfate and combined Fenton/ persulfate systems, Chem. Eng. J. 279 (2015) 452-462. 
[26] M. Feng, R. Qu, X. Zhang, P. Sun, Y. Sui, L. Wang, Z. Wang, Degradation of flumequine in aqueous solution by persulfate activated with common methods and polyhydroquinone-coated magnetite/multi-walled carbon nanotubes catalysts, Water Res. 85 (2015) 1-10.

[27] H. Guo, N. Gao, Y. Yang, Y. Zhang, Kinetics and transformation pathways on oxidation of fluoroquinolones with thermally activated persulfate, Chem. Eng. J. 292 (2016) 82-91.

[28] H. Tamura, K. Goto, T. Yotsuyanagi, M. Nagayama, Spectrophotometric determination of iron(II) with 1,10-phenanthroline in the presence of large amounts of iron(III), Talanta 21 (1974) 314-318.

[29] H. Herrmann, On the photolysis of simple anions and neutral molecules as sources of $\mathrm{O}^{-} / \mathrm{OH}, \mathrm{SO}_{\mathrm{x}}{ }^{-}$and $\mathrm{Cl}$ in aqueous solution, Phys. Chem. Chem. Phys. 9 (2007) 3935-3964.

[30] C. J. Liang, C. F. Huang, N. Mohanty, R. M. Kurakalva, A rapid spectrophotometric determination of persulfate anion in ISCO, Chemosphere 73 (9) (2008) 1540-1543.

[31] G. P. Anipsitakis, D. D. Dionysiou, Radical Generation by the Interaction of Transition Metals with Common Oxidants, Environ. Sci. Technol. 38 (2004) 3705-3712.

[32] Y. F. Rao, L. Qu, H. Yang, W. Chu, Degradation of carbamazepine by Fe(II)-activated persulfate process, J. Hazard. Mater. 268 (2014) 23-32.

[33] V. C. Mora, J. A. Rosso, G. Carrillo Le Roux, D. O. Mártire, M. C. Gonzalez, Thermally activated peroxydisulfate in the presence of additives: A clean method for the degradation of pollutants, Chemosphere 75 (2009) 1405-1409.

[34] A. B. Ross, W.G. Mallard, W.P. Helman, G. V. Buxton, R. E. Huie, P. Neta, 1998. NDRL-NIST Solution Kinetics Database. Ver. 3.0, Gaithersburg, MD, Available on the web at: <http://www.kinetics.nist.gov/solution/> (March 2008).

[35] E. Hayon, A. Treinin, J. Wilf, Electronic spectra, photochemistry, and autoxidation mechanism of the sulfite-bisulfite-pyrosulfite systems. The $\mathrm{SO}_{2}^{-}, \mathrm{SO}_{3}{ }^{-}, \mathrm{SO}_{4}^{-}$, and $\mathrm{SO}_{5}{ }^{-}$ Radicals, J. Am. Chem. Soc. 94 (1972) 47-57.

[36] G. Fang, D. D. Dionysiou, S. R. Al-Abed, D. Zhou, Superoxide radical driving the activation of persulfate by magnetite nanoparticles: Implications for the degradation of PCBs, Appl. Catal. B Environ. 129 (2013) 325-332.

[37] P. Neta, V. Madhavan, H. Zemel, R.W. Fessenden, Rate constants and mechanism of reaction of $\mathrm{SO}_{4}{ }^{-}$- with aromatic compounds, J. Am. Chem. Soc. 99 (1977) 163-164.

[38] G. V. Buxton, C. L. Greenstock, W. P. Helman, A. B. Ross, Critical review of rate constants for reactions of hydrated electrons, hydrogen atoms and hydroxylradicals $\left({ }^{\circ} \mathrm{OH} / \mathrm{O}_{2}{ }^{\circ}\right.$ -) in aqueous solution, J. Phys. Chem. Ref. Data. 17 (1988) 513-886. 
[39] D. Ding, C. Liu, Y. Ji, Q. Yang, L. Chen, C. Jiang, T. Cai, Mechanism insight of degradation of norfloxacin by magnetite nanoparticles activated persulfate: Identification of radicals and degradation pathway, Chem. Eng. J. 308 (2017) 330-339.

[40] B. A. Wols, C. H. M. Hofman-Caris, Review of photochemical reaction constants of organic micropollutants required for UV advanced oxidation processes in water, Water Res. 46 (2012) 2815-2827.

[41] T. An, H. Yang, W. Song, G. Li, H. Luo, WJ. Cooper, Mechanistic considerations for the advanced oxidation treatment of fluoroquinolone pharmaceutical compounds using $\mathrm{TiO}_{2}$ heterogeneous catalysis, J. Phys. Chem. A 114 (2010) 2569-2575.

[42] X. Wu, X. Gu, S. Lu , M. Xu, X. Zang, Z. Miao, Z. Qiu, Q. Sui, Degradation of trichloroethylene in aqueous solution by persulfate activated with citric acid chelated ferrous ion, Chem. Eng. J. 255 (2014) 585-592.

[43] W. J. McElroy, S. J. Waygood, Kinetics of the reactions of the $\mathrm{SO}^{-}$radical with $\mathrm{SO}_{4}$ $\mathrm{S}_{2} \mathrm{O}_{8}{ }^{2-} \mathrm{H}_{2} \mathrm{O}$ and $\mathrm{Fe}^{2+}$, in: G. Restelli, G. Angeletti (Eds.), Physico-Chemical Behaviour of Atmospheric Pollutants: Air Pollution Research Reports, Springer Netherlands, Dordrecht, 1990, pp. 251-256.

[44] X. Xue, K. Hanna, M. Abdelmoula, N. Deng, Adsorption and oxidation of PCP on the surface of magnetite: Kinetic experiments and spectroscopic investigations, Appl. Catal. B: Environ. 89 (2009) 432-440.

[45] A. Rastogi, S. R. Al-Abed, D. D. Dionysiou, Sulfate radical-based ferrousperoxymonosulfate oxidative system for PCBs in aqueous and sediment systems, Appl. Catal. B Environ. 85 (2009) 171-179.

[46] P. Neta, R. E. Huie, A. B. Ross, Rate constants for reactions of inorganic radicals in aqueous solution, J. Phys. Chem. Ref. Data. 17 (1988) 1027-1284.

[47] M. Sturini, A. Speltini, F. Maraschi, A. Profumo, L. Pretali, E.A. Irastorza, E. Fasani, A. Albini, photolytic and photocatalytic degradation of fluoroquinolones in untreated river water under natural sunlight, Appl. Catal. B Environ. 119-120 (2012) 32-39. S. Babic, M. Periša, I.

[48] Škoric, Photolytic degradation of norfloxacin, enrofloxacin and ciprofloxacin in various aqueous media, Chemosphere 91 (2013) 1635-1642. 


\section{Capture Figures}

Fig.1. Kinetic removals of FLU (a), NOR (b) and CIP (c) for various oxidation processes at $\mathrm{pH} 6.5 \pm 0.1:[\mathrm{FLU}]_{\mathrm{o}}=[\mathrm{NOR}]_{\mathrm{o}}=[\mathrm{CIP}]_{\mathrm{o}}=77 \mu \mathrm{M} ;[\mathrm{PS}]_{\mathrm{o}}=0.7 \mathrm{mM} ;[\text { Laterite }]_{\mathrm{o}}=1 \mathrm{~g} \mathrm{~L}^{-1}$; UVA irradiation; [ ] aq = concentration of pollutant removal in the liquid phase; [ ]tot $=$ total concentration of pollutant representing both aqueous (residual) concentration and adsorbed concentration obtained after desorption.

Fig.2. Effect of Isopr, Tert-b and BQ (a) and radical species involved (b) in PS/UVA/Laterite system after $540 \mathrm{~min}$ at $\mathrm{pH} 6.5 \pm 0.1$ : [Laterite $]_{\mathrm{o}}=1 \mathrm{~g} \mathrm{~L}^{-1} ;[\mathrm{PS}]_{\mathrm{o}}=0.7 \mathrm{mM} ;[\mathrm{NOR}]_{\mathrm{o}}=77 \mu \mathrm{M}$; $[\text { Isopr }]_{\mathrm{o}}=[\text { Tert-b }]_{\mathrm{o}}=[\mathrm{BQ}]_{\mathrm{o}}=100 \mathrm{mM}$; UVA irradiation.

Fig.3. Effect of PS concentration in presence of $1 \mathrm{~g} / \mathrm{L}$ laterite (a), and laterite loading in presence of $0.7 \mathrm{mM}$ PS (b) on FLU and NOR removals by PS/UVA/Laterite system at $\mathrm{pH} 6.5$ $\pm 0.1:[\mathrm{FLU}]_{\mathrm{o}}=[\mathrm{NOR}]_{\mathrm{o}}=77 \mu \mathrm{M} ;$ UVA irradiation; reaction time $=540 \mathrm{~min}$.

Fig.4. Degradation rate constants $\left(k_{a p p}\right)$ (a) and percentages (b) of FLU, NOR and CIP in single, binary and ternary systems at pH $6.5 \pm 0.1:[\mathrm{FLU}]_{\mathrm{o}}=[\mathrm{NOR}]_{\mathrm{o}}=[\mathrm{CIP}]_{\mathrm{o}}=19 \mu \mathrm{M}$; $[\text { laterite }]_{\mathrm{o}}=1 \mathrm{~g} \mathrm{~L}^{-1} ;[\mathrm{PS}]_{\mathrm{o}}=0.7 \mathrm{mM}$; UVA irradiation; reaction time $=300 \mathrm{~min}$.

Fig.5. Degradation rate constants $\left(k_{a p p}\right)$ (a) and percentages (b) of FLU, NOR and CIP in single, binary and ternary systems in synthetic wastewater $(\mathrm{SWW})$ at $\mathrm{pH} 6.5 \pm 0.1$ : $[\mathrm{FLU}]_{\mathrm{o}}=$ $[\mathrm{NOR}]_{\mathrm{o}}=[\mathrm{CIP}]_{\mathrm{o}}=19 \mu \mathrm{M} ;[\text { laterite }]_{\mathrm{o}}=1 \mathrm{~g} \mathrm{~L}^{-1} ;[\mathrm{PS}]_{\mathrm{o}}=0.7 \mathrm{mM}$; UVA irradiation; reaction time $=300 \mathrm{~min}$.

Fig.6. Degradation of FLU, NOR and CIP in three successive oxidation cycles of PS/UVA/Laterite system at pH $6.5 \pm 0.1:[\mathrm{FLU}]_{\mathrm{o}}=[\mathrm{NOR}]_{\mathrm{o}}=77 \mu \mathrm{M} ;[\mathrm{PS}]_{\mathrm{o}}=0.7 \mathrm{mM}$; $[\text { Laterite }]_{\mathrm{o}}=1 \mathrm{~g} \mathrm{~L}^{-1} ;$ UVA irradiation; reaction time $=540 \mathrm{~min}$. 

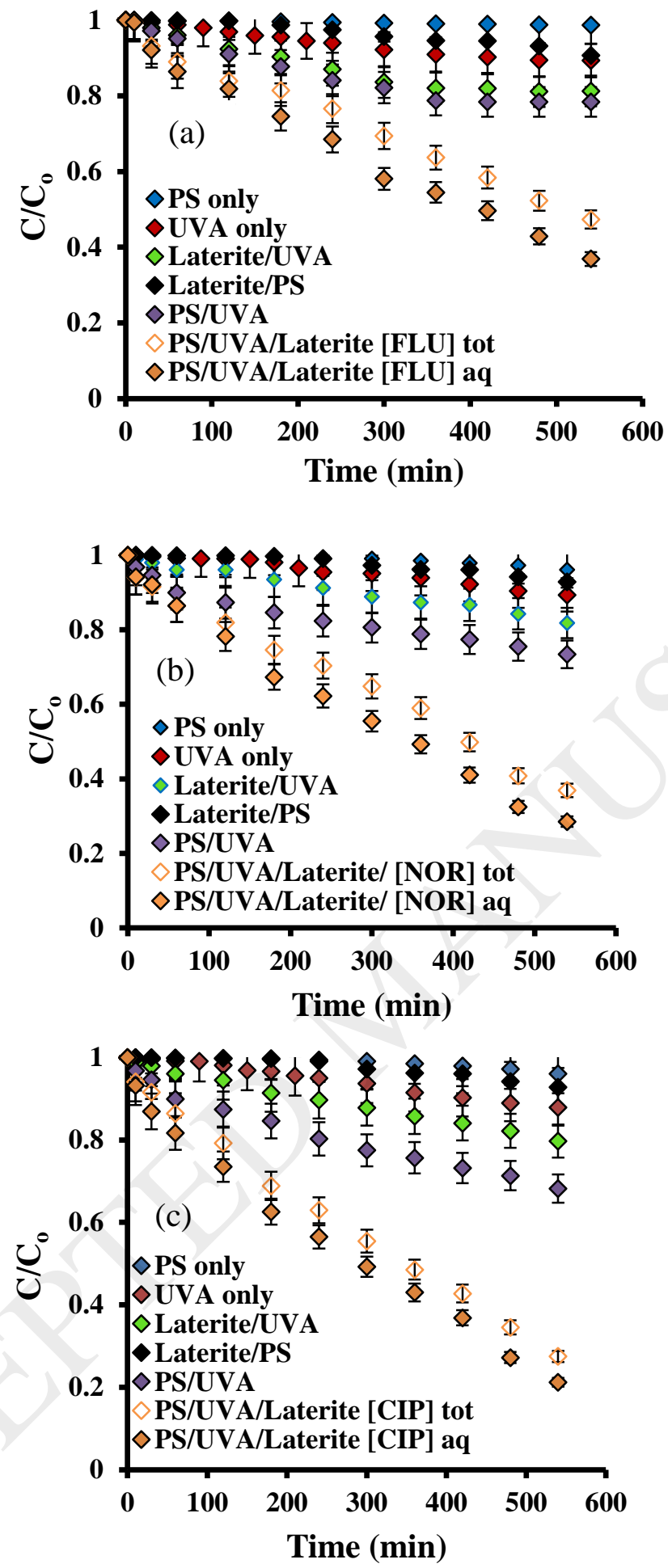

Fig. 1 

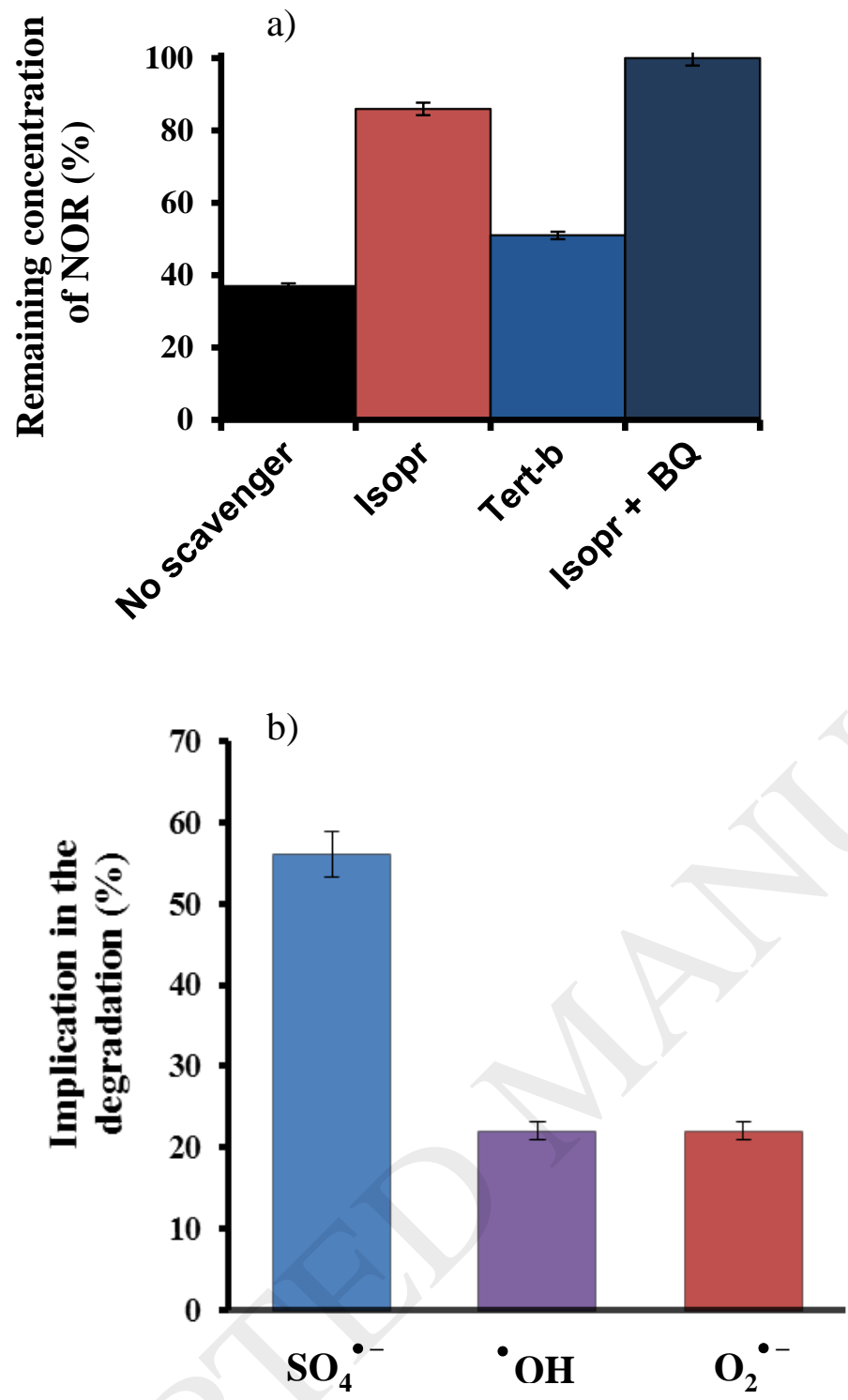

Fig. 2 

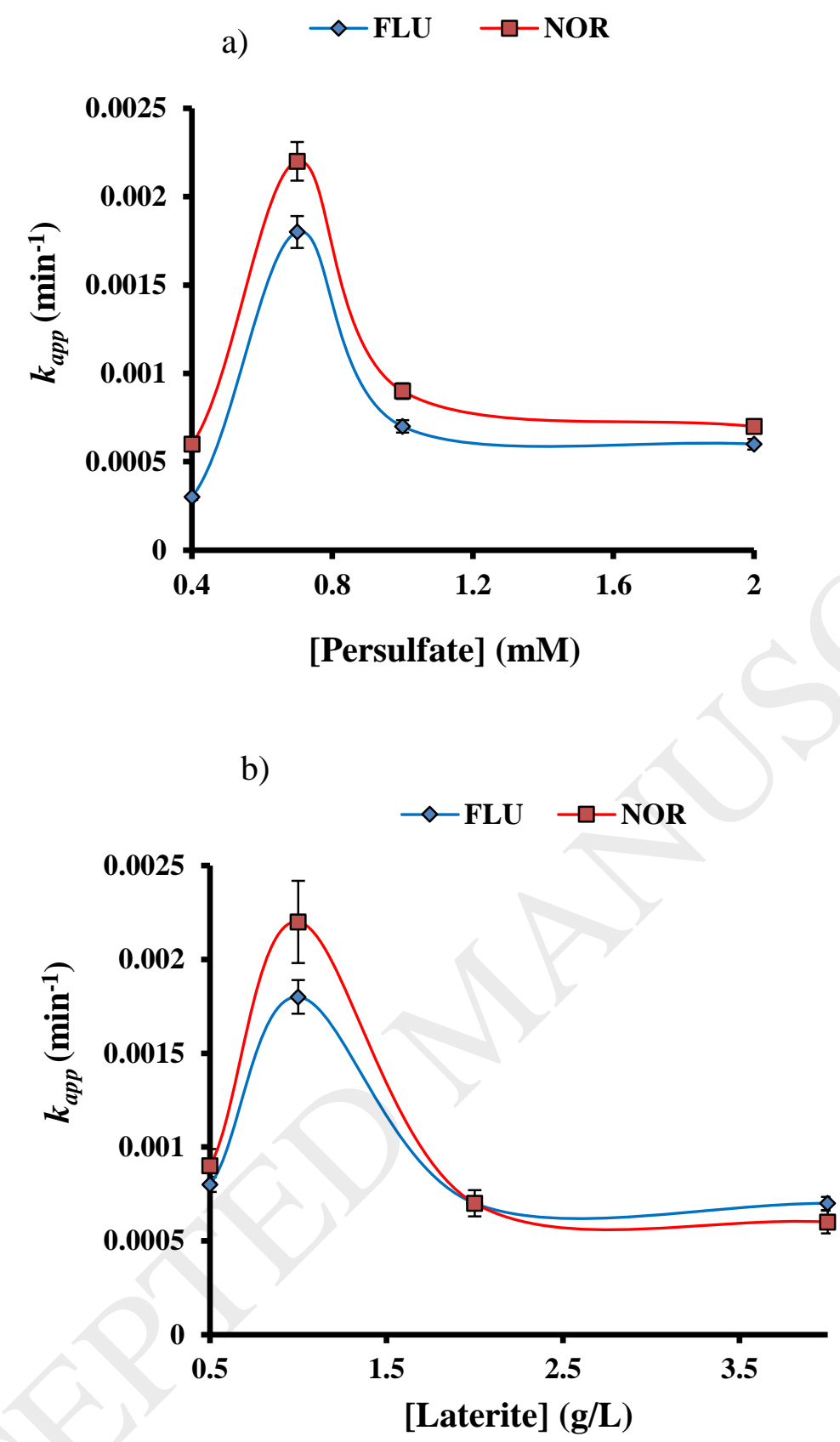

Fig. 3 

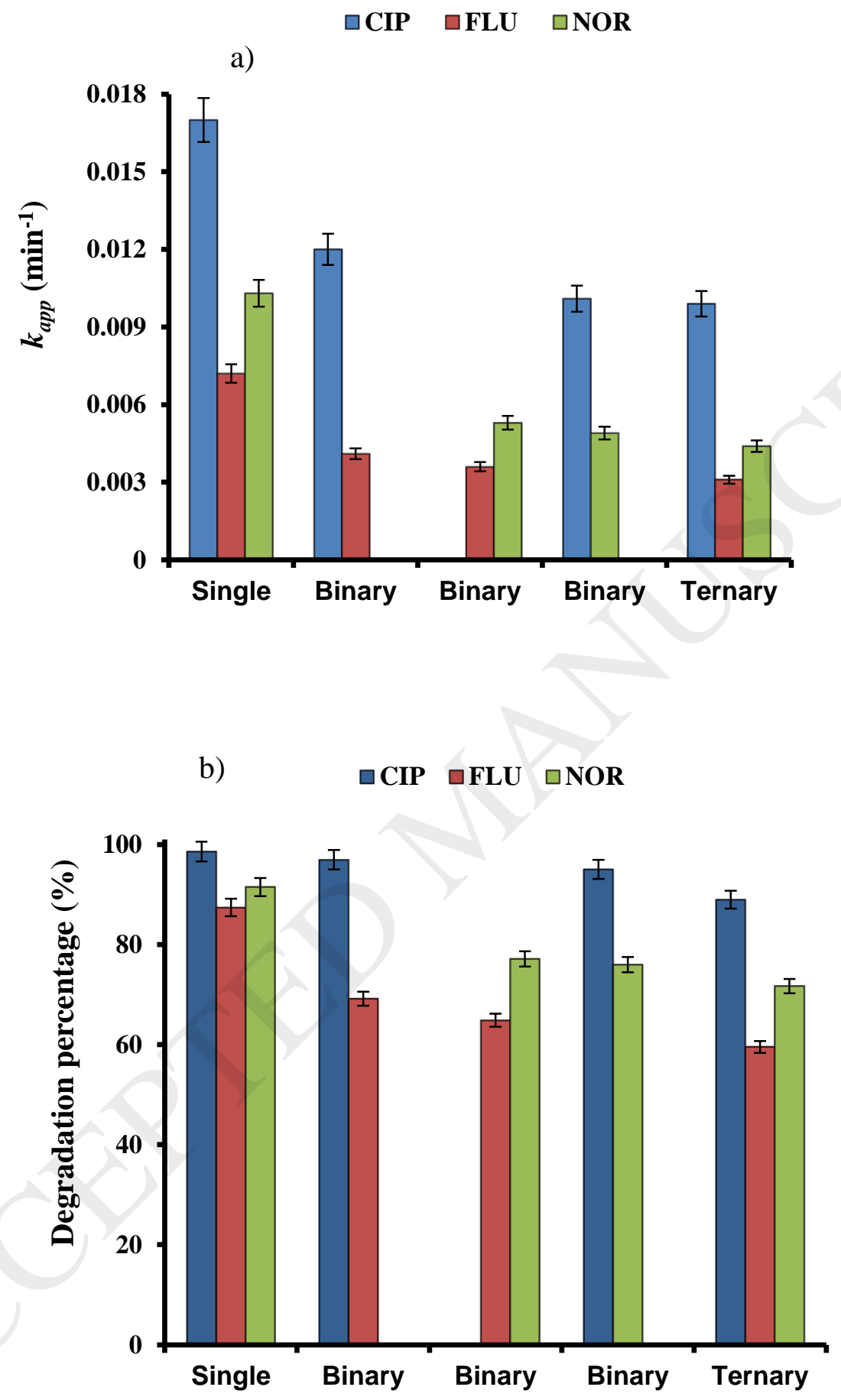

Fig. 4 
a)

$\square$ CIP $\square$ FLU $\square$ NOR

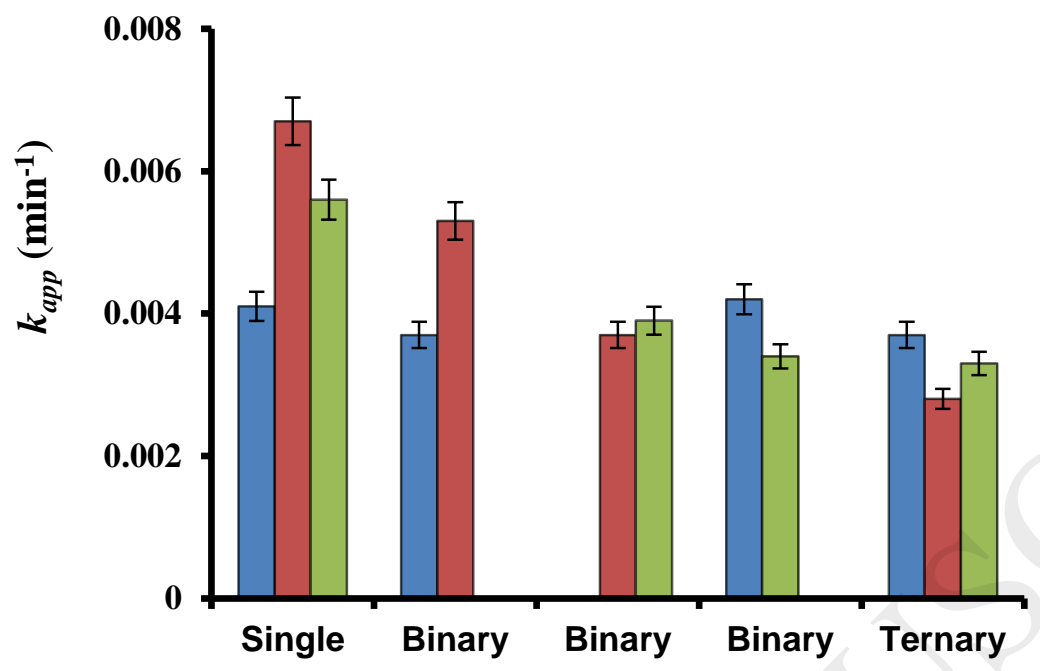

b)

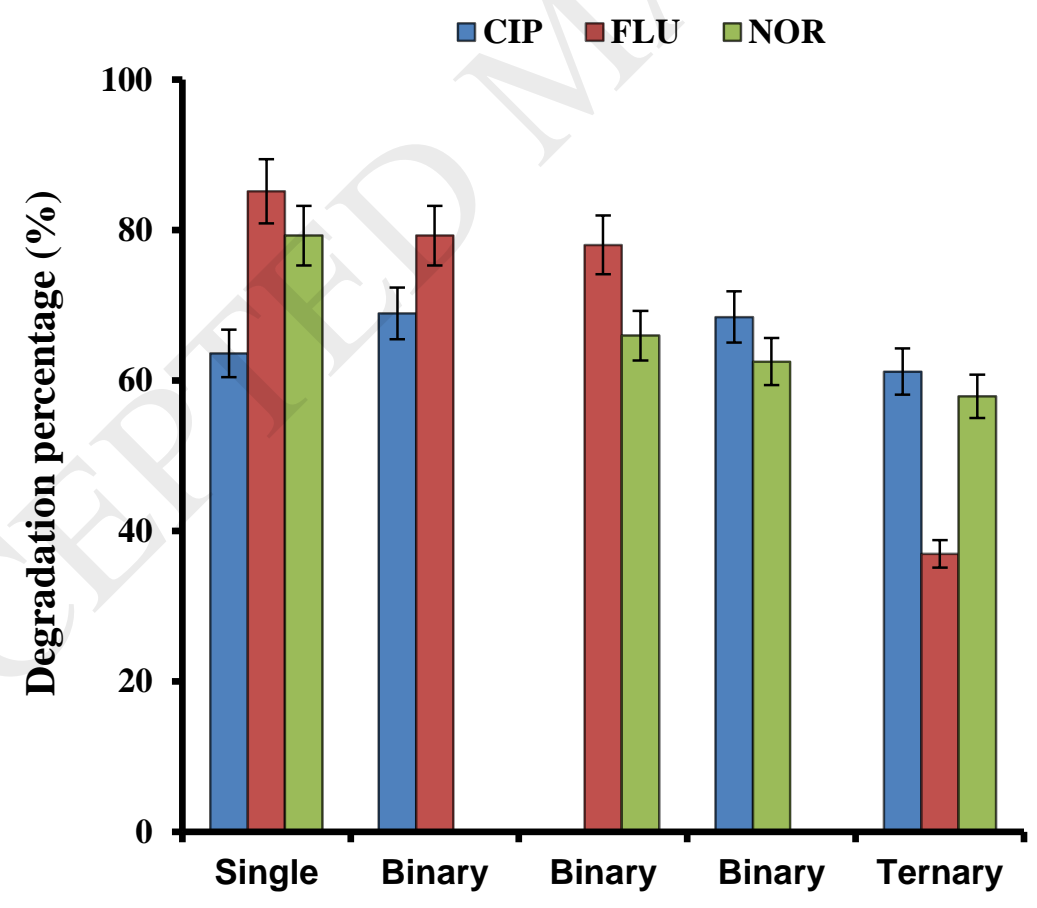

Fig. 5 


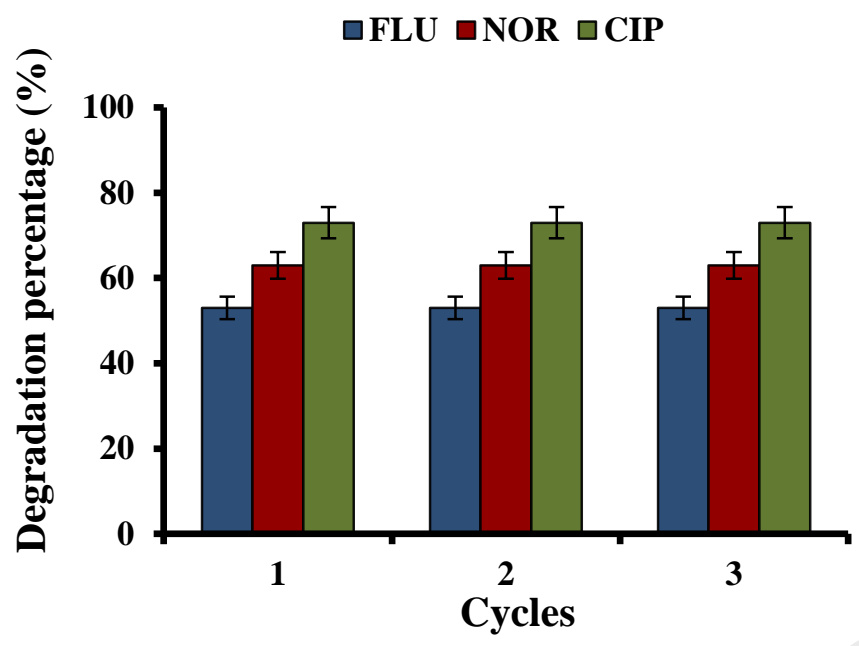

Fig. 6 